\title{
Use of bufferized dental anesthetics in dental
}

\section{surgery}

Uso de anestésicos dentários bufferizados em cirurgia dentária

Uso de anestésicos dentales buferizados en cirugía oral

Adel Martínez-Martínez ${ }^{1 \otimes c \text { culac }}$, Elio Jiménez-Batista ${ }^{2 \otimes}$, Alexander Morales-Jiménez $^{3 \otimes}$

1. Professor Department of Oral Medicine, GITOUC Group, School of Dentistry, University of Cartagena, Colombia.

2. Student of Stomatology and Oral Surgery, GITOUC Group, School of Dentistry, University of Cartagena, Colombia

3. Student of Stomatology and Oral Surgery, GITOUC Group, School of Dentistry, University of Cartagena, Colombia.

Fecha correspondencia:

Recibido: febrero de 2020.

Aceptado: diciembre de 2020.

Forma de citar:

Martínez-Martínez A, Jiménez-

Batista E, Morales-Jiménez A. Use

of bufferized dental anesthetics

in dental surgery. Rev. CES Odont

2021; 34(1): 35-43.

Open access

(C) Derecho de autor

Licencia creative commons

Ética de publicaciones

Revisión por pares

Gestión por Open Journal System

DOl: http://dx.doi.org/10.21615/

cesodon.34.1.4

ISSN 0120-971X

e-ISSN 2215-9185

\section{Abstract}

Introduction and objective: The addition of epinephrine to the anesthetic solution reduces the $\mathrm{pH}$ of the solution to a range between 2.9 and 4.4. The acidity of the anesthetic may delay onset and contribute to injection pain. Objective: to determine the intensity of pain during a mandibular third molar surgery after using buffered 4\% articaine with epinephrine 1:100000 in the inferior alveolar nerve block with buccal infiltration. Materials and methods: an observational and descriptive clinical study was performed. The buffered solution was alkalinized with $8.4 \%$ sodium bicarbonate with a ratio of $9: 1$, using a hand-mixing methodology, the sample were patients who required a mandibular third molar surgery. After standardizing the anesthetic technique, it was used the inferior alveolar nerve block followed by buccal infiltration. Results: 32 patients (20 female $-62.5 \%$ and 12 male - 37.5\%), with an average age of 21.12 years (mean \pm standard deviation [SD]: $21.12 \pm 3.61$ ) were admitted to the study. When assessing the pain puncture and during the injection, $94 \%$ of patients classified it as mild pain according to VAS. When evaluating the latency period, the average time was less than two minutes and the perioral soft tissue anesthesia was $62 \%$. Only a small percentage of patients required complementary anesthesia. Conclusion: buffered $4 \%$ of articaine with epinephrine in the inferior alveolar nerve block with buccal infiltration significantly decreased onset time, injection pain and need for complementary anesthesia in third molar surgery.

Keywords: Sodium bicarbonate; Carticaine; Anesthesia, Local; nerve block; dentistry.

\section{Resumo}

Introdução e objetivo: A adição de adrenalina à solução anestésica reduz o pH da solução para uma faixa entre 2,9 e 4,4. A acidez do anestésico pode atrasar o início e contribuir para a dor da injeção. Determinar a intensidade da dor durante uma cirurgia dos terceiros molares inferiores após o uso de articaína tamponada a 4\% com adrenalina 1: 100000 no bloqueio do nervo alveolar inferior com infiltração bucal. Materiais e métodos: foi 
realizado um estudo clínico observacional e descritivo. A solução tamponada foi alcalinizada com bicarbonato de sódio a 8,4\% com uma proporção de 9: 1, utilizando uma metodologia de mistura manual; a amostra era de pacientes que necessitaram de uma cirurgia de terceiros molares inferiores. Após padronização da técnica anestésica foi utilizada bloqueio do nervo alveolar inferior seguido de infiltração bucal. Resultados: 32 pacientes (20 mulheres - 62,5\% e 12 homens - 37,5\%), com idade média de 21,12 anos (média \pm desvio padrão [DP]: 21,12 $\pm 3,61$ ) foram admitidos no estudo. Ao avaliar a punção dolorosa e durante a injeção, 94\% dos pacientes a classificaram como dor leve de acordo com a EVA. Ao avaliar o período de latência, o tempo médio foi inferior a dois minutos e a anestesia perioral dos tecidos moles foi de $62 \%$. Apenas uma pequena porcentagem de pacientes necessitou de anestesia complementar. Conclusão: tamponar $4 \%$ de articaína com epinefrina no bloqueio do nervo alveolar inferior com infiltração bucal diminuiu significativamente o tempo de início, a dor da injeção e a necessidade de anestesia complementar em cirurgia de terceiros molares.

Palavras-chave: Bicarbonato de sódio; Carticaína; Anestesia Local; bloqueio de nervo; odontologia.

\section{Resumen}

Introducción y objetivo: la adición de epinefrina a la solución anestésica reduce el pH en un rango entre 2.9 y 4.4. La acidez del anestésico puede retrasar el inicio del efecto anestésico y contribuir al dolor durante la inyección de la solución. determinar la intensidad del dolor durante la cirugía de terceros molares mandibulares después de usar articaína al 4\% con epinefrina 1:100000 buferizada, en el bloqueo del nervio alveolar inferior con infiltración bucal. Materiales y métodos: se realizó un estudio clínico observacional y descriptivo. La solución buferizada se alcalinizó con bicarbonato de sodio al 8,4\% en una relación de 9:1, utilizando una técnica de mezcla manual, la muestra se obtuvo de pacientes que requerían cirugía del tercer molar mandibular. Después de estandarizar la técnica anestésica fue utilizado un bloqueo del nervio alveolar inferior seguido de una infiltración bucal. Resultados: 32 pacientes ( 20 mujeres $-62,5 \%$ y 12 hombres $-37,5 \%$ ), con una edad promedio de 21.12 años (media \pm desviación estándar [DE]: $21.12 \pm 3.61$ ) ingresaron al estudio. Al evaluar el dolor durante la punción y durante la inyección de la solución anestésica, el $94 \%$ de los pacientes lo clasificaron como dolor leve según la EVA. Al evaluar el período de latencia, el tiempo promedio fue inferior a dos minutos y la anestesia perioral de tejidos blandos fue del $62 \%$. Solo un pequeño porcentaje de pacientes requirió anestesia complementaria. Conclusión: El uso de 4\% de articaína con epinefrina buferizada, en el bloqueo del nervio alveolar inferior con infiltración bucal disminuyó significativamente el tiempo de inicio, el dolor durante la inyección y la necesidad de anestesia complementaria en la cirugía de terceros molares.

Palabras clave: bicarbonato de sodio; Carticaína; Anestesia local; bloqueo nervioso; cirugía de terceros molares.

\section{Introduction}

Local anesthetics (LA) are the safest and most effective drugs in the prevention and management of pain during a dental procedure, being lidocaine the most used anesthetic agent since its introduction in 1943, it is considered the gold standard of local anesthetics for dental use (1,2). All injectable local anesthetics are vasodilators and increased the blood flow through the injected area, so they provide a short duration 
and not as profound anesthesia. A vasoconstrictor is added to the local anesthetic solution to increase duration and depth reduce absorption and systemic toxicity by decreasing blood levels of the LA (3). The most used vasoconstrictor by dentists in the world is epinephrine or adrenaline. It is effective in preventing or minimizing blood loss during surgical procedures. If adrenaline is not added to lidocaine, vasodilating effect of lidocaine limits pulpal anesthesia to only 5-10 min. When the vasoconstrictor is added to the lidocaine the $\mathrm{pH}$ of this is acidified $(\mathrm{pH}: 3.5)$ and the percentage of un-ionized fraction is reduced to $0.004 \%$ compared to 24.03 of $\%$ un-ionized fraction of the plain lidocaine $(\mathrm{pH}: 7.4)$ by reducing the number of ions able to penetrate the lipid membrane $(6,000 \times$ less active ions to enter nerve). The acidity of the anesthetic may delay onset and contribute to injection pain. Some authors have proposed the use of lidocaine and others LA alkalinized with promising results in the faster onset and more comfortable injection (4-6). Alkalization of local anesthetics is achieved by adding $8,4 \%$ sodium bicarbonate, this allows more uncharged molecules or free bases, which are lipid soluble, readily cross lipid membranes, and lead to faster, more profound, and more effective local anesthesia clinically. This phenomenon of the fastest and deepest local anesthesia was described by Catchlove in 1972. Early in vitro studies demonstrated that buffering local anesthetics with $8.4 \%$ sodium bicarbonate can potentiate the nerve impulse-blocking action, Malamed $\mathrm{S}$ et al (7), conducted a clinical trial whose objective was compared anesthetic latency and injection pain for alkalinized versus non-alkalinized anesthetic in inferior alveolar nerve blocks. They demonstrate a statistically significant decrease in onset time when patients received buffered lidocaine with epinephrine compared to an unbuffered solution for an inferior alveolar nerve block. With the alkalinized anesthetic, $71 \%$ of participants achieved pulpal analgesia in 2 minutes or less. With non-alkalinized anesthetic, 12\% achieved pulpal analgesia in 2 minutes or less. When they assessed pain during the injection, the $72 \%$ of the participants rated the alkalinized injection as more comfortable and the $11 \%$ rated the non-alkalinized injection as more comfortable. Guo J et al (8), published in 2018 a meta-analysis with the purpose of evaluated the use of buffered versus non-buffered lidocaine to increase the efficacy of inferior alveolar nerve block. Eleven references were included, the results of the systematic review showed that buffered lidocaine showed 48 seconds faster onset time and 5.0 units lower (on a scale 0-100) VAS injection pain than non-buffered. These authors concluded that despite the fact that the buffered lidocaine significantly decreased onset time and injection pain (VAS) compared with non-buffered lidocaine, the statistical heterogeneity and low sample size the quality of the evidence was low to moderate, Additional studies with a greater number of participants and low risk of bias are necessary to confirm these results. In 2016, Chopra R et al (9) conducted a clinical trial in children with the purpose of assess the reduction in pain on injection during inferior alveolar nerve block administration, no significant differences were found between the assessed using the sound, eye, and motor (SEM scores) and the Heft-Parker visual analogue scale HP-VAS scores ( $P=0.93)$ for the two solutions used, so they conclude that buffered lidocaine did not reduce the pain on injection or time to onset of anesthesia for inferior alveolar nerve block in children. In USA, in 2010 the US Food and Drug Administration (FDA) approved the first chairside mixing device for buffering lidocaine known as Onset ${ }^{\circledR}$ (Onpharma, onpharma.com), this device allows dispensing the desired amount of sodium bicarbonate with the mixing pen via a numbered volume dial. The manufacturer recommends the addition of $0.18 \mathrm{~mL}$ for a 9:1 ratio of $2 \%$ lidocaine with 1:100,000 epinephrine to $8.4 \%$ sodium bicarbonate (10). In January 2015, Anutra Medical (anutramedical.com) received approval from the FDA for its disposable, feedback aspiration syringe (11). The main innovation of this system is that it allows dispensing up to $5 \mathrm{~mL}$ of buffered fluid, which is useful 
in procedures require the use of multiple local anesthetic cartridges and traditional aspiration dental syringes are limited to holding only one cartridge at a time (about $1.8 \mathrm{~mL}$ of fluid). The Anutra system buffers the local anesthetic solution at a 10:1, lidocaine to $8.4 \%$ sodium bicarbonate, ratio (12).

Therefore, the aim of this study was to evaluate the pain experience using buffered $4 \%$ articaine with epinephrine 1:100000 in surgical removal of mandibular third molars.

\section{Materials and methods}

Population: 32 voluntary patients were included in this observational and descriptive clinical study in which patients with indication of surgical removal of mandibular third molars, received an inferior alveolar nerve block with buccal infiltration using buffered $4 \%$ articaine with epinephrine 1:100000. This study was approved by the ethics committee of the University of Cartagena and all the patients completed an informed written consent to participate in it. Anesthesia protocol: The anesthetic cartridges were masked and coded by a third person who did not belong to the group of investigators and were delivered to the investigator at the time of the dental treatment. The patients were unaware of the content of the cartridges. This was unveiled after the tabulation of the information. Participants had to be between 18 and 30 years of age, be systemically healthy (ASA1). Patients with a history of hypersensitivity to anesthetics or its components, anxiety and consumption of drugs or substances that alter consciousness, those with infectious or inflammatory pathologies associated with the third molar and the neighboring molars, second and first molars that presented restorations, metallic, orthodontic appliances or immature apices were excluded. Methods: The subjects were operated on in a clinical session. The buffered solution was alkalinized with $8.4 \%$ sodium bicarbonate with a ratio of 9:1, using a hand-mixing methodology. To achieve a 9:1 local anesthetic to $8.4 \%$ sodium bicarbonate ratio, the total cartridge volume of $1.8 \mathrm{~mL}$ consisted of $1.62 \mathrm{~mL}$ of local anesthetic and $0.18 \mathrm{~mL}$ of $8.4 \%$ sodium bicarbonate. A $50 \mathrm{~mL}$ vial of $8.4 \%$ sodium bicarbonate was used to buffer the local anesthetic solutions. The buffered local anesthetic samples of 9:1 ratio of local anesthesia to $8.4 \%$ sodium bicarbonate were mixed using the remove and replace strategy previously published for Goodchild JH et al (13). $0.18 \mathrm{~mL}$ of local anesthetic solution was removed from the cartridge using a $0.5 \mathrm{~mL}$ syringe with a 28 -gauge, 0.5 -inch needle (BD micro-fine Insulin Syringe-BD company, bd.com) using a separate unused syringe, $0.18 \mathrm{~mL}$ of the commercially available $8.4 \%$ sodium bicarbonate was removed from the $50 \mathrm{~mL}$ vial and immediately injected into the local anesthetic cartridge. 5 minutes after the solution alkalized, $0.9 \mathrm{~mL}$ of the buffered solution was applied to the inferior alveolar nerve and $0.9 \mathrm{~mL}$ in a buccal infiltration. Assessment of pain: The patients were instructed to inform the investigator of any episode of injection pain (VAS) and during the different surgical times of the surgery, which if moderate to severe according to a visual analogue scale (Helf-Parker), indicated a complementary injection (intraligamentary) with the same anesthetic solution that was being evaluated at the time. Sociodemographic data, injection pain, latency period, pain during the surgery, complementary anesthesia and complications were evaluated. Statistical analysis: The statistical analysis of the data was developed using frequency measurements (\%), as well as averages and standard deviation according to the nature of the variables. The quantitative variables were evaluated depending on the normality of the data using the Shapiro Wilk statistic. The chi-square test was used to compare proportions. All results were considered statistically significant when the P-value was $<.05$. The analysis was performed using Stata statistical software v.13.2 for Windows (Stata Corp, TX, USA). This study was classified as a risk investigation greater than 
the minimum according to Article 11 of resolution 8430 of 1993 of the Ministry of Health and Social Protection of Colombia, in which the confidentiality of information was reserved for not requesting the name of the patient who signed the informed consent respecting the decision not to fill it when he did not want to participate in the study, reason that excluded the patient from the project. The study was undertaken in full accordance with ethical principles, including the World Medical Association declaration of Helsinki.

\section{Results}

32 patients ( 20 female $-62.5 \%$ and 12 male $-37.5 \%$ ), with an average age of 21.12 years (mean \pm standard deviation [SD]: $21.12 \pm 3.61$, table 1). Table 1 shows distribution of age, sex and age range.

Table 1. Distribution of age, sex, and age range.

\begin{tabular}{|c|c|}
\hline $\operatorname{Age}(y)$, mean $\pm S D$ a & $21.12 \pm 3.61$, Range $18-30$ \\
\hline Gender ${ }^{a}$ & $\mathrm{n}(\%)$ \\
\hline Male & $12(37.5 \%)$ \\
\hline Female & $20(62.5 \%)$ \\
\hline Age Range & $n$ \\
\hline $18-21$ & 14 \\
\hline $22-24$ & 10 \\
\hline $25-27$ & 5 \\
\hline $28-30$ & 3 \\
\hline
\end{tabular}

The table 2 shows the injection pain, $94 \%$ of patients classified it as mild pain according to VAS (score:1). The highest intensity of pain was reported in the dislocation, VAS score of 3 (mild pain). When evaluating the latency period, the average time was less than two minutes and the perioral soft tissue anesthesia was $62 \%$.

Table 2. Pain puncture and during injection.

\begin{tabular}{|c|c|c|}
\hline Injection Pain puncture -VAS & $N$ & $\%$ \\
\hline 0 & 8 & 25 \\
\hline 1 & 12 & 37.5 \\
\hline 2 & 6 & 18.7 \\
\hline 3 & 5 & 9.3 \\
\hline 4 & 1 & 12.5 \\
\hline Pain during the surgery & VAS & Score \\
\hline Incision & & 0 \\
\hline Flap detachment & & 0 \\
\hline Osteotomy & & 1 \\
\hline Odontosection & & 2 \\
\hline Dislocation & & 3 \\
\hline Suture & & 0 \\
\hline
\end{tabular}


Only a small percentage of patients required complementary anesthesia, $36 \%$ required an intraligamentary technique and $20 \%$ intrapulp anesthesia (table 3 ). No complications related to the local anesthetic, anesthesia technique and surgical intervention were reported.

Table 3. Latency period, Soft tissue anesthesia and Complementary anesthesia.

\begin{tabular}{|c|c|}
\hline Latency period (minutes), mean $\pm S D$ & $\begin{array}{c}1.3 \pm 0.2 \\
\text { Range:2.02 }-1.0 \text { minutes }\end{array}$ \\
\hline Soft Tissue Anesthesia & $\%$ \\
\hline Yes & 62 \\
\hline No & 38 \\
\hline Complementary anesthesia & $\%$ \\
\hline Yes & 36 \\
\hline No & 64 \\
\hline Type of complementary anesthesia & $\%$ \\
\hline Intraligamentary & 36 \\
\hline Intrapulp & 20 \\
\hline
\end{tabular}

\section{Discussion}

Articaine with adrenaline or epinephrine has shown promising results when used in a buccal infiltration after an inferior alveolar nerve block, many studies have shown that articaine $4 \%$ is more effective than lidocaine $2 \%$ in obtaining successful pulpal anesthesia in mandibular molars after a supplemental buccal infiltration (14-16). But when adding a vasoconstrictor such as adrenaline, the $\mathrm{pH}$ of the anesthetic solution is acidified, going from a pH of 6.5 to a $\mathrm{pH}$ of 3.5. This acidification is due an antioxidant (most commonly sodium bisulfite) is added to the solution, lowering the $\mathrm{pH}$ to approximately 3.5. The acidification of the local anesthetic reduces to less than $0.1 \%$ the percentage of non-ionized fraction or free base, which can penetrate the lipid bilayer of the nerve fiber, to then exert its action when joining the channel sodium-dependent voltage of the cytoplasmic side (17). The acidity of the anesthetic may delay onset and contribute to injection pain. The authors evaluated the injection pain, latency period, pain during the surgery, complementary anesthesia and complications finding by using buffered articaine in third molar surgery. The pain was reduced during the puncture, the latency period was less than two minutes, only a small percentage of patients required complementary anesthesia and no complications were reported. Kashyap VM et al in 2011 (18), reported a clinical trial in 100 patients aged 18-55 years who were given a conventional mandibular block (inferior alveolar, lingual, and long buccal), this study was designed to assess the effect of alkalinisation of the lidocaine solution with sodium bicarbonate. The results were like those reported in the present study, no patient who received the sodium bicarbonate injection complained of pain and the mean time (SD) until the start of local anesthesia in the group that received sodium bicarbonate was less than one minute. The difference between the studies is that the clinical trial of Kashyap VM was in 100 patients and related a comparison between buffered and non-buffered lidocaine, the authors used buffered articaine in inferior alveolar nerve block with buccal infiltration and the sample was smaller. 
The findings of our study were like studies conducted by Kurien RS et al (19) and Malamed SF et al (20), who found that buffered anesthetic solutions with sodium bicarbonate significantly decreased pain of injection and faster onset with alkalinized $2 \%$ lidocaine with epinephrine 1:100,000. However, this contrasted with study by Whitcomb M et al (21) who found no faster onset of pulpal anesthesia and no significant pain reduction with buffered anesthetic solutions.

Shurtz R et al (22) compared 4\% articaine with 1:100,000 epinephrine buffered with $8.4 \%$ sodium bicarbonate $(18 \mathrm{mEq})$ and $4 \%$ articaine with 1:100,000 epinephrine in a single primary mandibular first molar buccal infiltration, no significant differences were found between the 2 formulations for pain of injection or onset of anesthesia. The results regarding onset of anesthesia were higher than those reported in the present study ( $5.9 \pm 5.9$ minutes vs $1.3 \pm 0.2$ minutes). Gazal $G$ et al (23), compared two buffered solutions ( $4 \%$ articaine and $2 \%$ mepivacaine) for upper teeth extractions, investigated the speed of action and injection discomfort. Articaine buccal injection was significantly more painful than mepivacaine buccal injection (t-test: $P<0.001$ ). However, articaine palatal injection was less painful than articaine buccal injection. These authors used no-buffered solutions and the score of pain with VAS was higher than the results of the present trial when using buffered articaine. Guo J et al (24), performed a systematic review for evaluated the use of buffered versus non-buffered lidocaine to increase the efficacy of inferior alveolar nerve block (IANB). They conclude as in the present study, that buffered lidocaine significantly decreased onset time and injection pain (VAS) compared with non-buffered lidocaine in IANB. However, the quality of the evidence was low to moderate, the authors recommend that additional studies with larger numbers of participants and low risk of bias are needed to confirm these results.

\section{Conclusions}

The use of buffered articaine in inferior alveolar nerve block with buccal infiltration in third molar surgery showed that it produced pain reduction during the injection, less pain during the extraction especially in dislocation and faster onset.

\section{Acknowledgments}

The authors report no conflicts of interest.

\section{References}

1. Malamed SF. Handbook of Local Anesthesia, 7th ed. St.Louis: Mosby-Year Book; 2019.

2. Allegretti CE, Sampaio RM, Horliana AC, Armonia PL, Rocha RG, Tortamano IP. Anesthetic Efficacy in Irreversible Pulpitis: A Randomized Clinical Trial. Braz Dent J 2016 27(4):381-386.

3. Tanaka E, Yoshida K, Kawaai H, Yamazaki S. Lidocaine concentration in oral tissue by the addition of epinephrine. Anesth Prog 2016 63(1):17-24.

4. Malamed SF, Hersh E, Poorsattar S, Falkel M. Faster onset and more comfortable injection with alkalinized 2\% lidocaine with epinephrine 1:100,000. Compend Contin Educ Dent 2013 34(1):1-11. 
5. Malamed SF, Falkel M. Advances in local anesthetics: $\mathrm{pH}$ buffering and dissolved C02. Dent Today. 2012 May 31(5):88-93.

6. Malamed SF, Falkel M. Buffered local anesthetics: the importance of $\mathrm{pH}$ and $\mathrm{CO} 2$. SAAD Dig. 2013 Jan 29:9-17.

7. Malamed SF, Hersh E, Poorsattar S, Falkel M. Faster onset and more comfortable injection with alkalinized 2\% lidocaine with epinephrine 1:100,000. Compend Contin Educ Dent 2013 34(1):10-20.

8. Guo J, Yin K, Roges R, Enciso R. Efficacy of sodium bicarbonate buffered versus non-buffered lidocaine with epinephrine in inferior alveolar nerve block: A meta-analysis. J Dent Anesth Pain Med 2018 18(3):129-142.

9. Chopra R, Jindal G, Sachdev V, Sandhu M. Double-Blind Crossover Study to Compare Pain Experience During Inferior Alveolar Nerve Block Administration Using Buffered Two Percent Lidocaine in Children. Pediatr Dent. 2016 38:25-29.

10. Onpharma Sodium Bicarbonate Inj., 8.4\% USP Neutralizing Additive Solution [package insert]. Carson City, NV: Onpharma Co; 2017. http://www.onpharma. com/pdf/Onpharma Sodium\%20Bicarbonate Additive Solution Package Insert.pdf. Accessed June 20, 2019.

11. US Dept of Health and Human Services. 510(k) approval letters. Silver Spring, MD: Food and Drug Administration; January 8, 2015. https://www.accessdata. fda.gov/cdrh docs/pdf14/K143757.pdf. Accessed June 20, 2019.

12. Anutra Medical Receives 510k Approval and Launches New Dental Syringe to Market. Triangle Park, NC: Anutra Medical; January 8, 2015. http://anutramedical.com/wp-content/uploads/2015/04/Anutra-Medical-Receives-510k-Approval-and-Launches-New-Dental-Product.pdf. Accessed June 20, 2019.

13. Goodchild JH, Donaldson M. Comparing the pH change of local anesthetic solutions using two chairside buffering techniques. Compend Contin Educ Dent 2016 37(5):e6-e12.

14. Bartlett G, Mansoor J. Articaine buccal infiltration vs lidocaine inferior dental block - a review of the literatura. Br Dent J 2016220 (3):117-120.

15. Rogers B.S, Botero T.M, McDonald N.J, Gardner R.J, Peters M.C. Efficacy of articaine versus lidocaine as a supplemental buccal infiltration in mandibular molars with irreversible pulpitis: a prospective, randomized, double-blind study. J Endod 2014 40(6):753-758.

16. Da Silva-Junior G.P, de Almeida Souza L.M, Groppo F.C. Comparison of Articaine and Lidocaine for Buccal Infiltration After Inferior Alveolar Nerve Block for Intraoperative Pain Control During Impacted Mandibular Third Molar Surgery. Anesth Prog 2017 64(2):80-84.

17. Malamed SF, Falkel M. Buffered local anesthetics: the importance of $\mathrm{pH}$ and $\mathrm{CO}$. SAAD Dig. 2013 29:9-17. 
18. Kashyap VM, Desai R, Reddy PB, Menon S. Effect of alkalinisation of lignocaine for intraoral nerve block on pain during injection, and speed of onset of anaesthesia. Br J Oral Maxillofac Surg 2011 Dec 49(8):e72-75.

19. Kurien RS, Goswami M, Singh S. Comparative evaluation of anesthetic efficacy of warm, buffered and conventional $2 \%$ lignocaine for the success of inferior alveolar nerve block (IANB) in mandibular primary molars: A randomized controlled clinical trial. J Dent Res Dent Clin Dent Prospect 2018 12(2):102-109.

20. Malamed SF, Hersh E, Poorsattar S, Falkel M. Faster onset and more comfortable injection with alkalinized 2\% lidocaine with epinephrine 1:100,000. Compend Contin Educ Dent 2013 34(1):1-11.

21. Whitcomb M, Drum M, Reader A, Nusstein J, Beck M. A prospective, randomized, double-blind study of the anesthetic efficacy of sodium bicarbonate buffered $2 \%$ lidocaine with 1:100,000 epinephrine in inferior alveolar nerve blocks. Anesth Prog 2010 57(2):59-66.

22. Shurtz R, Nusstein J, Reader A, Drum M, Fowler S, Beck M. Buffered 4\% Articaine as a Primary Buccal Infiltration of the Mandibular First Molar: A Prospective, Randomized, Double-blind Study. J Endod 2015 41:1403-1407.

23. Gazal G, Alharbi R, Fareed WM, Omar E, Alolayan AB, Al-Zoubi H, Alnazzawi AA. Comparison of onset anesthesia time and injection discomfort of $4 \%$ articaine and 2\% mepivacaine during teeth extractions. Saudi J Anaesth 2017 Apr-Jun 11(2):152-157.

24. Guo J, Yin K, Roges R, Enciso R. Efficacy of sodium bicarbonate buffered versus non-buffered lidocaine with epinephrine in inferior alveolar nerve block: A meta-analysis. J Dent Anesth Pain Med 2018 18(3):129-142. 